\title{
The Environmental and Ethical Issues of Nuclear Power and Ionizing Radiation
}

\author{
Hayrettin Kilic \\ The Green Think Tank of Turunch Foundation, Hoboken, N.J 07030, USA
}

\begin{abstract}
As we enter the new millennium, population explosion, increasing worldwide energy demands and rapid global increase in ionizing radiation are all now threatening our fragile environment like no other time in known history. There is an urgent need for research and education to focus on the complex and direct link between ionizing radiation and its irreversible impact on the environment. Hence, nuclear energy and ionizing radiation issues can no longer be viewed in isolation. Historical facts and official reports prove that a code of ethics did not previously exist in nuclear industry: the risks of ionizing radiation are too great and unpredictable. Elimination of existing man-made ionizing radiation sources in this century is untenable and unsustainable. The intent of this paper is to review and demonstrate that 'Atoms for Peace' is a false and unethical enterprise, and offers insights into the social and ethical aspects of ionizing radiation as a result of nuclear power development. The unethical nature of nuclear weapons, along with risk perception and ethical dilemmas of atom for peace, nuclear weapon tests, the International Atomic Energy Agency, the Nuclear Non-Proliferation Treaty, the International Court of Justice's opinion and the World Economic Forum-Global Risk Landscape will be discussed.
\end{abstract}

Key words: Nuclear energy, ethical issues, ionizing radiation.

\section{Introduction}

As in 2017, millions of people are living within a few miles radius of existing nuclear power plants, nuclear research complexes and nuclear waste sites throughout the world. Most of these nuclear facilities are built without an 'Environmental Impact Assessment'. 'Some of the 21 nuclear power plants have a population larger than 7 million people living within a $30 \mathrm{~km}$ radius. Six of the power plants have populations larger than 3 million living within this radius' [1].

As stated in the Los Alamos Report in August 1981, "There is no technical demarcation between the military and civilian reactor and there never was one." Currently thirty states have operating nuclear power plants and forty two countries have fissionable material to produce nuclear weapons. Twenty two of these

Corresponding author: Hayrettin Kilic, Ph.D., nuclear physicist, research fields: safety and environmental aspects of nuclear power. countries have the capability to produce enriched uranium-235 or to separate plutonium-239. Thirteen of these countries are active in producing enriched uranium and separating plutonium. Nine of these countries: the USA, Russia, China, England, France, India, Pakistan, Israel and North Korea have nuclear weapon stockpiles totaling more than 13.800 warheads of which 4.825 have already been deployed [2].

Unfortunately, the last 20 years of global efforts to promote the entry into force of the CTBT (Comprehensive Test Ban Treaty), the treaty's complete ratification are a long way off.

As of 2016, eight 'Annex 2' states have not ratified the CTBT treaty: China, Egypt, Iran, Israel and the United States have signed but not ratified the Treaty: India, North Korea and Pakistan have simply not signed it. Collectively, all nuclear states possess more than 250 tons of weapon grade Plutonium 239.

By the end of the last century, the number of civilian and military nuclear reactors around the world reached more than 600 , most of which were built without 
environmental impact assessments, and even during normal operation, collectively they have been a chronic source of ionizing radiation which recognizes no boundaries. In addition, throughout the nuclear fuel cycle, billions of tons of radioactive milling and enrichment waste, millions of tons of toxic radioactive liquid waste, and huge amounts of spent fuel are cumulatively generated worldwide. Due to non-existing permanent geological repositories, most of these spent fuel assemblies are stored at reactor sites. Between 1946 and 1993, during the 48-year history of sea disposal, 14 countries have used more than 80 sites to dispose millions of curies of high level radioactive waste into our oceans [3].

The nuclear weapon tests and nuclear power plant accidents, which strike civilians and combatants indiscriminately, endanger the human environment in a manner which threatens the entirety of life on our planet, and also violate the Universal Declaration of Human Rights. Presently, nuclear energy and the nuclear weapons industry still share technology and finance as silent partner for breeding pure uranium-235 and plutonium-239 for the new generation nuclear weapons. During the last 60 years, the nuclear weapon states: the United States, Russia, France, England, China, India, Pakistan and Israel produced more than 80,000 nuclear weapons and 2050 of which have been detonated in oceans, underground, and in the atmosphere, creating a new man-made global ionizing radiation background forever.

\section{A Global Perspective: Who Is on the Frontline of Ionizing Radiation?}

The latest research and measured data on ionizing radiation reflects a sobering fact that there is no dose of 'safe-radiation limits', which are still open to interpretation from special interest pro-nuclear groups. Ionizing radiation, in any shape and form, does not recognize national boundaries. It is non-partisan, and has no scent. Accuracy of diagnosis and monitoring ionizing radiation doses in humans and the food chain is still being developed only after theThree Mile Island and Chernobyl accident. However, the nuclear industry is still very powerful and it exerts control of collection and dissemination of information relating to the environmental aspects of ionizing radiation.

The Colombia University (NY, USA) and British Nature Magazine carried out an analysis concerning population density around the existing nuclear power plants throughout the world (Although this study ignored the research labs and waste sites). It turns out that: " $2 / 3$ of the world's 211 power plants have more people living within a 30 kilometer radius. Some of the 21 power plants have a population larger than 7 million within a $30 \mathrm{~km}$ radius. 6 of the power plants have populations larger than 3 million. The Kanupp plant in Karachi, Pakistan has 8.2 million people living within a $30 \mathrm{~km}$ radius. The 1993 megawatt Kuosheng power plant in Taiwan has 5.5 million within a $30 \mathrm{~km}$ radius, and the 1208 megawatt Chin Shan plant has 4.7 million. Chinese Guangdong and Lingao nuclear power plants are each surrounded with a population of 28 million people including Hong Kong region. The Indian Point power plant, 20 miles away north of New York City-Manhattan with 17.3 million people. The Narora power plant in Uttar Pradesh, India with 60 million people within a $75 \mathrm{~km}$, if the radius is extended to $150 \mathrm{~km} 79$ million people in New Delhi" [1].

All commercial, military and research nuclear facilities, during their normal operation routinely release radioactive isotopes and toxic substances through their stacks into the atmosphere and into the water. Each nuclear power plant has an inventory of every element in the periodic table, including tritium, carbon, strontium, iodine, cesium, krypton, argon and xenon, which are dispersed in the air and contaminate both local water and soil. It is clear to many policy makers, (especially in Europe) that environmental, technological, financial and social issues surrounding the use of nuclear energy are inescapable and the damages that they cause are real. 


\subsection{Why the Public should be Cconcerned with Ethical Issues of Nuclear Industry}

Nuclear power plants, directly or indirectly, have been a risk to human health from past, current and future accidents. They disrupt society through health, economics and displacement. Ethical openness of politicians and the nuclear industry has been always 'sluggish' and insufficient in some countries. Moreover, the following facts from the International Atomic Energy Agency's official report show the gravity of global risks that the public is facing in every aspect of their lives.

"In 2013, 42\% of the world's nuclear power reactors had been in operation for more than 30 years, and another $7 \%$ for more than 40 years. Managing these reactors in the long term continues to pose challenges that need to be addressed and integrated into all operational aspects relevant to safety. Furthermore, in $2013,70 \%$ of the world's research reactors have been in operation for more than 30 years with over half of them in operation for more than 40 years. The safety and availability of research reactors continues to be challenged by ageing-related failures" [4].

In 2014, the OSART (Operational Safety Review Team), as a part of their missions, conducted a three year investigation. This report also provides results on managing safety issues in 19 nuclear power plant sites between 2010 and 2012. The following safety issues in directly relation to leadership, human behavior, awareness of risks and the management system were commonly found at nuclear power plants.

"Deficiencies were not systematically identified and reported (50\% of the sites) Material conditions and housekeeping were not at the expected standards $(60 \%$ of the sites) Personal protective equipment was not used systematically (50\% of the sites). Contamination control practices and measures to prevent spreading of contamination were often insufficient $(70 \%$ of the sites). Management of fire loads and maintenance of firefighting equipment were lacking (80\% of the Sites)" [5].
The IAEA (International Atomic Energy Agency), the United Nations Agency were created for the purpose of promoting, coordinating, directing, reporting of international nuclear affairs, including (but not limited to) preventing proliferation of sensitive nuclear materials, regulating nuclear research labs and power plants and facilitating collaboration between industry and operators. However, considering the last 40 years of its performance, and the sobering facts outlined in their own report above show that the IAEA has been slow to act in response to every major accidents and has inadequately performed its duties.

\section{Ethics}

"The Ethics and logic of Science are Universal. They transcend geographic frontiers and ideological divides." Joseph Rotblat. Nobel Peace Laureate 1995.

The main areas about risk and ethical issues of ionizing radiation for which the 'pro' and 'anti' nuclear positions differ deeply and fundamentally. Ethics consists simply of the actions an individual takes on himself/herself. It is self-determinism. Distinguishing right from wrong conduct. Differentiating good from evil. 'Moral' is usually defined as a code of good conduct based on experience to serve as a uniform measure for conduct of individuals and groups. The Criteria of individual ethics may differ in different cultures and in professional morality.

Professional ethics set standards that are often higher than that of individual-morality; professional bodies are created to ensure that these standards are adhered to a common ethic/morality; common ethics are conceptualized as a set of shared norms and principles that the majority of reasonable and thinking people in society would like to see them realized. Common morality is considered as a point of reference in public decision making. It has been a useful political tool that is available for the politicians as a basis for the evaluation of any public decision making. 


\section{Fundamental Principles of Ionizing Radiation}

The universe comprises stable non-radioactive atoms and unstable radioactive atoms. Ionizing radiation is produced by unstable atoms often called radionuclides or isotopes, which differ from stable atoms because they have an excess of energy or mass, or both, and in order to reach stability, these atoms give off, or emit, the excess energy or mass. These emissions are called radiation in general and ionizing radiation when entering an absorbing medium cause direct ionization byprotons, alpha particles, beta particles, positron particles and indirect ionization by neutrons, gamma rays and x-rays.

Ionizing radiation, in general, transfers its energy to matter in the form of 'structured tracks' of charged particles. The main difference between direct and indirect ionization is that: radionuclides (Cesium-137 and Uranium-235) are primarily unstable chemical elements with the similarities and reactivates of the non-radioactive forms of these elements. "They will therefore have distinct specific biochemical pathways in the living organisms and may accumulate at positions in cells as a result of their chemical group, valence, ionic volumes, and charge. However, photon radiation (gamma and $\mathrm{x}$-ray radiation) is absorbed by matter mainly through Compton Effect, Photoelectron, and Pair-production, all of which cause the creation of tracks of energetic electrons which carry the energy of the original photon and collide with molecules in the absorbing medium causing ionization. The ionized fragments (in the case of living tissue mainly of water) then recombine or react with local molecular entities causing chemical changes in the molecular structure" [6.]

\subsection{Quantifying Ionizing Radiation}

The RAD (Radiation Absorbed Dose) is a measure of the absorbed dose of the energy deposited in a material. One RAD is the deposition of one hundred 'ergs' of energy in one gram of any material (US, NRC Regulations use per gram of body tissue) due to the ionization from any type of radiation. In general, the 'Rad-Rate' is defined as a time of exposure. However, there are still uncertainties and not a broad consensus in determining biological effects of acutely delivered doses and doses delivered at low dose-rates. The REM (Roentgen Equivalent Man) is based on the biological damage caused by ionization in human body tissue. It is a term for dose equivalence and equals the biological damage that would be caused by one RAD of dose.

The REM accounts for the fact that not all types of radiation are equally effective in producing biological change or damage. That is, the damage from one RAD deposited by beta radiation is less than that caused by one RAD of alpha radiation. Therefore, the REM is numerically equal to the dose in RAD multiplied by a quality factor: the RBE (Relative Biological Effectiveness), a quantity which does not assume any bio-physical structure in the living tissue being irradiated, only accounts for numerical difference in the amount of biological damage caused by the different types of radiation.

\subsection{Ever Changing Radiation Exposure Limits}

The amount of the dose of radiation that the public can be exposed to over a certain period of time has been subject to superficial changes by the nuclear regulatory authorities and varies in different countries, ranging from 100 to 200 milli-rems per year. However, according to Christopher Busby, Jacobs University, Bremen, Germany, "The current assessment of harm from radiation exposure is based on a quantity (REM) which does not assume any structure in the tissue being irradiated. It does not Aspects of DNA Damage from Internal Radionuclides distinguish between different radionuclides on the basis of their chemical properties except at the organ level (Iodine/thyroid) and it does not include any weighting for chemical affinities for DNA, nor for transmutation effects. It 
does not consider the fractionation of doses within cell cycle repair times. Risk factors are based almost on acute external gamma ray exposures."

DNA is made from Carbon, Oxygen, Hydrogen and Nitrogen: energy delivered by Ionizing radiation directly or indirectly, that is energetic enough to break any chemical bonds in the living tissue can create irreversible effects by causing mutations in genetic material both at the somatic level (cellular DNA) and embryo cell level (heritable mutations). "The mutations are caused by alterations in the cellular DNA in the nucleus and in mitochondria. These are brought about by three mechanisms: A. direct ionization of the DNA and subsequent chemical alteration of the bases to molecules which are not recognized as a coding signal. $\mathrm{B}$. indirect ionization of the DNA by reactive species produced by ionization of water (called Reactive Oxygen Specie, ROS). C. A mechanism termed "Genomic Instability" which is an inducible cell-cell signal consequence of the production of ROS in the cytoplasm (non-DNA region) of an irradiated cell. This process is communicable between cells in some way and even between individuals and has been termed the "bystander effect".

'Genetically induced malformations, cancers and numerous other health effects in the children of populations who were exposed to low doses of ionizing radiation have been unequivocally demonstrated in scientific investigations. Using data from Chernobyl effects we find a new ERR for CM of 0.5 per $\mathrm{mSv}$ at $1 \mathrm{mSv}$ falling to 0.1 per $\mathrm{mSv}$ at 10 $\mathrm{mSv}$ exposure and thereafter remaining roughly constant. This is for mixed fission products as defined though external exposure to Cs-137. Results show that current radiation risk models fail to predict or explain the many observations and should be abandoned. Further research and analysis of previous data is suggested, but prior assumptions of linear dose response, assumptions that internal exposures can be modelled using external risk factors, that chronic and acute exposures give comparable risks and finally dependence on interpretations of the high dose ABCC studies are all seen to be unsafe procedures' [7].

\section{Unethical Conduct of Nuclear States and Nuclear Power Plant Operators}

The risk and benefits of nuclear power reflect a complex interplay of safety and profit, a paradox that is created by the nuclear industry and IAEA. So far, uncertainty and ambiguity, from the cradle to the grave the nuclear cycle have been the norm in the nuclear industry under the umbrella of federal protection and of the IAEA. Any affective enforcement of the IAEA safety measures to match the risks and benefits of nuclear energy, and the health effects of ionizing radiation have faced numerous economic and political obstacles in different countries. In the wake of the Fukushima tragedy, the nuclear industry, IAEA and WHO, are still collaborating in very dangerous tendency to over simplify the irreversible unforeseen environmental and health consequences of existing global contamination, which may be lingering well into coming centuries.

\subsection{Deny, Delay, Deceive}

In the last 60 years, widespread corruption of the nuclear industry had created profound undeniable health and environmental consequences. Gross unethical conduct of the nuclear industry and nuclear regulatory authorities is evident and well documented in both nuclear energy technology exporting countries such as: Russia, Chine, US, the European Union, Canada, South Korea, Argentina and Japan, and also importing countries such as India, Pakistan, Iran, Turkey and the United Arab Emirates.

The nuclear industry is still being provided with a great deal of protection and financial support by the nuclear states, while the ability of the public to scrutinize and intervene in the industry's activities was effectively restricted. The U. S. Congressional Budget Office estimated nuclear power plant 
construction costs from 1966 to 1977, when most light water reactors in the U.S. were built, and found that the quoted cost for these 75 plants was $\$ 89.1$ billion, but the real cost was $\$ 283.3$ billion [8]. These cost overruns have very likelihood of affecting future plants. Nuclear power therefore needs significant subsidies in order to "compete" in the marketplace. Douglas Koplow looked at five decades worth of subsidies data and concluded that "subsidies to the nuclear fuel cycle have often exceeded the value of the power produced. This means that buying power on the open market and giving it away for free would have been less costly than subsidizing the construction and operation of nuclear power plants" [9].

It was only in some European countries, during the early 80 s, that new legislations were introduced, by which a new approach to regulations, such as 'Environmental Impact Assessment' was established. Because of this, the public has a greater ability to influence regulatory decisions in all topics relevant to the process of addressing environmental issues in implementing nuclear power programmers. Until then, the development of the nuclear cycle was very much a forgone-sacrificed conclusion, with little hope for the public to be able to intervene in the decision of the nuclear power development process.

\subsection{Code of Conduct of the Nuclear Industry: Leak before Break}

The nuclear industry has been overconfident that a major nuclear accident is 'impossible'. During the last 60 years, deliberate cover ups and misleading information have become a code of conduct of the industry. At many accidents they distressed the NES (Nuclear Event Scale), (invented by the nuclear cartel, a level that indicates the severity of the accident) and selectively, they reported numerous chronic serious near misses in power plant accidents as 'low level' incident. However, the TMI, Chernobyl and Fukushima accidents are undeniable testament to the importance of nuclear crises, which have no boundaries and indeed extend far beyond conventional NES expectations.

Corruption remains endemic: a web of deception; the TEPCO, IAEA and WHO are collaborating on a campaign of misinformation about prolonged release of radiation from TMI, Chernobyl, Fukushima and all the nuclear storage waste sites. In the last five years, TEPCO kept circulating deliberately altered daily statuses of plant's emission of radio isotopes on their web-sites. In fact, in January 2013 the TEPCO admitted (with an usual dry apology) that they had misinformed the authorities about the status of reactor number 1 right from the onset of accident.

In July 2001, the National Diet of Japan published the following statement "The TEPCO Fukushima Nuclear Power Plant accident was the result of collusion between the government, the regulators and TEPCO, and the lack of governance by said Parties. They effectively betrayed the nation's right to be safe from nuclear accidents. Therefore, we conclude that the accident was clearly "manmade." We believe that the Root causes were the organizational and regulatory systems that supported faulty rationales for decisions and actions, rather than issues relating to the competency of any specific individual." Published in July 2011, The National Diet of Japan. Masao Yamazaki, the Fukushima Nuclear Accident Independent Investigation Commission. In fact that, Chimari Naito, the former Vice President of Kansai Electric Power Co. (KEPCO-Japan), has admitted that he secretly paid seven of Japan's Prime Ministers about \$ 200.000 on an annual basis for 18 years. Since the onset of the Fukushima nuclear accidents, thousands of unskilled laborers have hired by the Japanese nuclear industry, who are often poorly trained and not protected against radiation.

Notorious executives with no ethics: from the beginning of peaceful use of nuclear energy, hundreds of nuclear industry executives and regulatory authorities have been arrested on the grounds of corruption. The following latest cases clearly showed 
that unethical conduct of the industry still lingered in every step of the nuclear cycle. On July 28th, 2014, the former President of the Korea hydro and Nuclear Power Company (KEPCO-Korean), Kim Jong Shin, along with 100 officers was arrested as part of an ongoing investigation into nuclear industry corruption inside of South Korea. Sergei Shutov, director of the Zio-Podosik Company, a subsidiary of Russian Atomenergomash-Posatom, was arrested for providing low quality materials for Russian built reactors around the world.

In Brazil, Othon L. Pinheiro da Silva, one of the chief executives of the state owned nuclear power utility Eletrobras, along with a dozen high level officers, was arrested on July 28th, 2015. In November 2014, US authorities also arrested the director of Rosatom's fuel supply arm, Vadim Mikerin, during an FBI sting operation Miker in is alleged to have accepted bribes of around \$1.7-million from three American businesspeople in exchange for tenders.

\section{Nuclear Fuel Resources Are Finite. Nuclear Waste Last Indefinitely}

The following information and figures in this section are based on the IAEA report: 'Estimation of Global Inventories of Radioactive Waste and Other Radioactive Materials, June, 2007 [3]. "The total amount of uranium produced worldwide up to the year 2004, is approximately 2.2 million tons, and the remaining uranium reserves worldwide is approximately 5 million tons". To date, uranium has been the only tax-exempt energy fuel, and on a worldwide scale, is readily accessible; high-grade uranium deposits will soon be exhausted, but the nuclear waste that have generated will be an irremediable global inheritance for the next generations. About 70 percent of the world's uranium reserves are located on lands owned by indigenous people.

Uranium mining and milling destroys their villages, deprives them of their farmland and pastures and contaminates their water. In the US there are still
14,000 abandoned open uranium mine pits that continued to pollute the local environment. Currently, neither technological solution nor geological repository exists for these permanent man-made reservoirs of ionizing radiation created by nuclear industry. Following is a brief summary of officially existing/reported radioactive waste which are permanent ionizing sources generated as result of the processing of only 2.2 million tons of uranium until 2004.

Tailings: Radioactive substances contained in the tailings have contaminated both air and groundwater for thousands of years. As a result of extracting and milling 2.2 million tons from uranium mines, the first step of the nuclear energy cycle, more than one thousand times more 'low level' radioactive solid milling waste was created. "Assuming also the quantity of mine residues to be equal to that of mill tailings, the estimated worldwide total inventory of both types of waste is about 1.3 billion tons. Taking average tailings density (tons $/ \mathrm{m}^{3}$ ) of 1.5 gives an estimated volume for each type of tailings of about 900 million meter cubes. Assuming a specific activity of the mill tailings, for both $230 \mathrm{Th}$ and $226 \mathrm{Ra}$, of $0.033 \mathrm{GBq} / \mathrm{m}^{3}$ their total radioactive inventory for both long lived radionuclides would be about 30,000 TBq. Assuming also that the specific activity of mine residues is lower by a factor of 10 the resulting radioactive inventory of mine residues would be about 3,000 TBq of uranium. Regarding the worldwide inventory of tailings generated as a result of defense activities, the estimates have been obtained considering the global production of warheads equal to 70,000 and assuming that each warhead has caused the production of 2,000 tons of both mine and mill tailings". According to the US EPA records, approximately there still exist 4,000 open uranium pits which have produced 3 billion tons of waste in the USA alone.

Global Amounts of Spent Fuel: the amount of spent fuel discharged from a nuclear power plant depends upon the fuel 'burn up' i.e., the thermal energy (heat) 
generated per unit mass of fuel. As for the end of 2009, in addition to millions of tons of spent fuel already reprocessed during the cold war, "nuclear fuel the total amount of spent fuel cumulatively generated worldwide were about 240,000 metric tons (as heavy metal) of spent fuel in storage worldwide, most of it at reactor sites. About $90 \%$ was in storage ponds, the balance was indry-cask storage. The annual spent fuel generated is approximately 10,500 tons of heavy metals per year, with roughly 8,500 tons of heavy metal going into long term storage and about 2,000 tons of heavy metal allocated for reprocessing but much of it being in interim storage" [3].

Reprocessing Nuclear Fuel Waste in Plutonium Factories: reprocessing of burnt fuel assembly generated in nuclear reactors creates 2,000 times more new liquid and solid radio-toxics of nuclear waste. In fact, they were built during the Cold War to extract pulutomium-239 isotope that is created during the chain reaction in nuclear fuel assembly; only about 1 per cent of reprocessed nuclear fuel waste is a commercially valuable uranium-235 fuel element. "United States of America: The total volume of high level reprocessing waste (HLW) stored at US sites, by the year 1996, was $347,300 \mathrm{~m}^{3}$. Spent fuel reprocessing waste in Russia, combined solid waste: 6 million $\mathrm{m}^{3}$, liquid waste; 23 million $\mathrm{m}^{3}$, underground: 12 million meter cube" [3]. So for, the US government spent more than $\$ 13$ billion on vilification project; mixing reprocessed waste with glass, with no success on the Harford site, known as the most polluted site in the US.

TRU (Transuranic Waste): Worldwide estimates of the quantities of radioactive waste generated by defense activities in Russia, China and Europe are highly uncertain. Only in the USA is radioactive waste containing uranium isotopes classified as TRU. In the USA 1.4 million $\mathrm{m}^{3}$ of TRU has been produced and isolated in various sites: Hartford, Oak Ridge, Rack Flats and Savannah River sites [3].

Nuclear Power Plants and Marine Life: According to the USA, California State's official report 'California water quality scope-doc 03808. 2008': 'Ironically, with all of the Limitations and prohibitions placed on discharges, impingement and entrainment have essentially constituted a permitted fish kill for power plant intake systems. The reality is, however, that a power plant cooling system does not discriminate and instead causes mortality to all aquatic life in the intake water column'. 'California power plants also annually entrain about 80 billion biological specimens, of which approximately 60 percent (48 billion) are larval fish. In addition, 57 marine tetrapods (seals, sea lions or sea turtles) are impinged annually. Of these tetrapods, roughly 50 percent are killed. The largest volumes of entrainments (approximately 10 billion) associated with the active nuclear generating stations, Diablo Canyon and San Onofre-SONGS, with design flows of 2,670 and 2,587 MGD respectively [10].

Inventory of Radioactive waste Disposals at Sea: In 1975, the Convention on the Prevention of Marine Pollution by Dumping (nuclear) Wastes and Other Matter, known as the London Convention was ratified by most of the IAEA's member states and entered into force on 30th of August, 1975. Based on the information that has been admitted by nuclear states, the IAEA published a report titled 'The Inventory of Radioactive Waste Disposals at Sea [11]'.

This report addresses disposal of clandestine radioactive waste in the Atlantic, Pacific and Arctic Oceans, a practice which continued from 1946 to 1993 by the nuclear industry. It also includes detailed official information on geographical and temporal sea disposal operations carried out by the United States, Belgium, England, France, Germany, the Netherlands, Sweden, Switzerland, Italy, Japan, South Korea and the former Soviet Union and the Russian Federation.

"The first reported sea disposal operation of radioactive waste took place in 1946 and the latest in 1993. During the 48 year history of sea disposal, 14 countries have used more than 80 sites to dispose of 
approximately $85 \mathrm{PBq}$ (2.3 Million Curies) of radioactive waste." [11]

According to this report: European countries have dumped 130,000 tons, Japan alone has more than 600,000 tons, the USA 90,463 containers including unknown amount of radioactive waste and Russia: 314,831 cubic meter of liquid, 53,504 cubic meters of solid waste along with six reactors and spent fuel have been dumped into our oceans.

\section{Beginning of Unethical Atomic Age}

In order to put ethical issues of nuclear industry into a historical perspective, following is a brief summary of the landmarks of the nuclear industry. In October, 1945, President Truman sent a message to congress and proposed creating a U.S AEC (atomic energy commission) to promote and develop the use of nuclear energy for peaceful means or otherwise. In the meantime, U.S congress proved unchallenged legal means to the establishment of a powerful AEC, as per President Truman's order, which was charged to keep the U.S monopoly of nuclear energy/weapons as the first priority, and promote the peaceful use of nuclear energy. At the same time the Soviet Union started their nuclear program marking the beginning of the Cold War. In the USA, between 1973 and 1974, at the peak of the cold war, 15 new nuclear plants were completed in one year without environmental impact assessments being carried out.

An ethic of extraordinaire: "Don't forget Los Alamos is Our Enemy, Russians Are Our Competitors." The AEC started an aggressive nuclear power research program at Los Alamos, Oak Ridge, Sandia and Argonne Laboratories, and in the major universities focusing on both nuclear weapon design and nuclear power plants. Secrecy relating to nuclear power programs at these research centers was to be maintained at the highest level and the death penalty would be prescribed for anybody passing secrets to a foreign country. The AEC created a toxically competitive atmosphere among the US research centers. A group of researchers in the Sandia lab hung a sign on a wall of their coffee room, saying: "Don't forget Los Alamos is our enemy, Russians are our competitors."

Between 1946 and 1996, the former Soviet Union, the USA, France, England, China, India, Pakistan, Israel and South Africa, conducted more than two thousand nuclear weapon tests some of which were carried out within their own territories. Other weapon tests were mostly conducted at more remote locations such as: Pacific Islands and Novaya Zemlya. France and the United Kingdom carried out their tests at the sites located in Algeria and Australia, the French and the United Kingdom in the Pacific Islands. Global fallout from these nuclear weapon tests is still lingering in the earth's atmosphere and is still affecting marine life.

Between 1964 and 1996, while the NPT (Nuclear Non-Proliferation Treaty) was in effect as an International hallow Treaty, China carried out at least 40 atmospheric nuclear explosions at the Lop Nur site in the Xinjiang region, where 20 million inhabitants mostly Uygur minorities, were exposed to high levels of radiation. Dr. Takada who studied the records of Chinese explosions estimated that: "1.2 million people received high level of radiation and at least 194,000 uninformed people eventually died as a result of acute radiation exposure" [12].

In March 1944, the Bikini Atoll was purchased by the US Government for a sum of ten dollars. In January, 1946 the Bikini Atoll became the first site for the first nuclear weapon test site after the Second World War. Between March 1st and May 14th, 1954 six Hydrogen bombs were tested, totaling 48 megatons. The first was known as Bravo, 1,000 times more destructive than the bomb at Hiroshima. The so called Castle series, Hydrogen bomb explosions, totaling 23 million curies, were dispersed into the stratosphere.

The Tsar Bomba: the single, most kinetically and radiological powerful nuclear weapon device ever 
deployed by mankind was designed by a team of Russian physicists headed by Academician Yulii Borisovich Khariton and included Andrei Sakharov, Victor Adamsky, Yuri Babayev, Yuri Smirnov and Yuri Trutnev. On October 30th, 1961, a 50 megaton TNT equivalent Hydrogen bomb, the largest nuclear bomb ever assembled, the so called 'TSAR-BOMBA' (officially called RDS-220), weighing 27 tons, was detonated $4.2 \mathrm{~km}$ above ground, in the Sukhoy Nostest range of the North Arctic Ocean.

The 'mushroom cloud' was about 64 kilometers (40 mi) high (over seven times the height of Mount Everest), which meant that the cloud was above the stratosphere and well inside the of mesosphere when it peaked. The cap of the mushroom cloud had a peak width of 95 kilometers $(59 \mathrm{mi})$ and its base was 40 kilometers $(25 \mathrm{mi})$ wide, breaking windows in Norway and Finland. Despite being detonated $4.2 \mathrm{~km}$ above ground, its seismic body wave magnitude was estimated at 5-5.25. Sensors continued to identify the shockwaves after their third trip around the world [13].

\subsection{Environmentally Friendly Nuclear Weapons}

The Mother and Father of all nuclear bombs: in September 18th, 2007, Russia announced the completion of successful testing of the 'Father of All Bombs' - four times more powerful than the USA's comparatively equable 'Mother of All Bombs'. Both nuclear devices are dubiously claimed to be environmentally friendly alternatives to the conventional nuclear devices. These types of bombs' capabilities are comparable to nuclear weapons, but unlike nuclear weaponry known for its radioactive fallout, use of the weapon does not damage or pollute the environment beyond the blast radius as they leave no radioactive fallout. When a typical Father or Mother bomb explodes, 40 tons of TNT equivalents are donated above the ground and most damage is inflicted by a supersonic shockwave at extremely high temperatures [14].

The thermobaric weapon: Thermobaric weapons differ from conventional or nuclear explosive weapons in that they generate a longer, more sustained blast wave with greater temperatures. During this type of explosion, thermobaric weapons produce more damage over a larger area than a conventional or nuclear weapon of similar energy/mass. The 'Fuel-Air Bomb' or 'Fuel Air Explosives' is one of the most well-known types of thermobaric weapons. This type of explosives that utilizes oxygen from the surrounding air to generate an intense, high-temperature explosion, and in practice the blast wave typically produced by such a weapon is of a significantly longer duration than a conventional condensed explosive.

A Human Rights Watch report of 1 February 2000 [15], quotes a study made by the US Defense Intelligence Agency: The blast kill mechanism against living targets is unique-and unpleasant What kill is the pressure wave, and more importantly, the subsequent rarefaction vacuum, which ruptures the lungs. If the fuel deflagrates but does not detonate, victims will be severely burned and will probably also inhale the burning fuel. Since the most common FAE fuels, ethylene oxide and propylene oxide, are highly toxic, undetonated FAE should prove as lethal to personnel caught within the cloud as most chemical agents.

\subsection{First Ethical Opposition to Nuclear Power}

First ethical lawsuit against nuclear states: from 1950 until 1980, the US government and weapon industry were in opposition to the establishment of a radioactive protection and remediation standards in Marshall Islands. In 1986, the US removed itself as a trustee of the Marshall Islands. As a result, the Independent Republic of Marshall Islands was established (RMI). In 2015, the RMI filed two lawsuits, based on NPT article V.I and Customary International Law. One in the US Federal Court against the US, which was dismissed by a US Federal Judge in Feb. 2015, and one in the ICJ (International Court of Justice) against to nine countries that detonated nuclear 
weapons and still possessed nuclear weapons, namely; the US, the UK, France, Russia, China, India, Pakistan, North Korea and Israel.

Scientific resilience begins on the level of individuals: unfortunately many scientists have become increasingly complacent with political parties. A fundamental distinction needs to be made between socially 'responsible' scientists and 'lifeless and mindless nuclear weapons' scientists. The nuclear energy and nuclear weapons establishments around the world have used these ill-tempered self-centered scientists until today. Enrico Fermi, one of the founders of modern nuclear physics describes them in his famous statement that: "A Monomaniac with Much Mania."

In March, 1946, a committee formed in the USA produced a report, known as the Acheson-Lilienthal report 'The Acheson-Lilienthal Report on the International Control of Atomic Energy in Washington, D. C. March 16. Signed by; Chester I. Barnard, J. R. Oppenheimer, Charles A. Thomas Harry A. Winne D. E. Lilienthal', containing some alarming conclusions about the reciprocal nature of nuclear energy and nuclear weapons development, and most importantly, the risk of nuclear weapon proliferation. The committee board determined that: 'the pursuit of atomic energy and atomic bombs were in the large part, interchangeable and interdependent'and pointed out that the uncontrolled exploitation of atomic energy by national governments cannot be safeguarded.

Russell Einstein Manifesto Press Conference 1955: the manifesto urged that war must be abolished and the world's scientists must: "Assemble in conference to appraise the perils that have arisen as a result of the development of weapons of mass destruction." And the first Pugwash Conference for the nuclear disarmament was organized by two former nuclear weapon program scientists: J. Rotblat and Szilard in 1957, and up to this date the Pugwash movement has been a very influential organization for comprehensive nuclear test band treaties.
The Soviet Union scientist involvement in the Pugwash meetings was closely monitored by a soviet secret service, the KGB. The leader of the Soviet Pugwash group was Mikhail Milioshchikov, the Vice-president of Soviet Academy of Science. But, Lev Artsimovich and Andrei Sakharov and Peter Kaptizka could not attend the Pugwash meetings because they began speaking out against nuclear weapons and were put under the house arrest in Russia shortly after the Tsar Bomba was detonated. Professor Landau, a member of the group who developed the nuclear program in Russia was also arrested by Stalin, when he escaped Russia and joined the Pugwash movement.

\subsection{Ethics or Politics}

Ironically, in one of the American and Russian joint meetings, when the Pugwash organizers asked the Soviet representative participants to sign a joint statement denouncing nuclear weapons; the Russian delegation response was to have a single statement that both parties agree to sign Americans could agree that "we do not believe in Capitalism." And Russians say that "we do not believe in Communism".

The first ethical public debate in the USA. February 20, 1958, KQED TV, California. A historical public debate accrued between Nobel laureate in chemistry and peace activist Prof. L. Pauling, and pronuke militarist Dr. E. Teller. Pauling, whose passport was revoked by the US state department at that time, said that "We should make our choice known with respect to the political significance of science." E. Teller, so called one of the 'fathers' of the hydrogen bomb, said that: "It is not scientist's job to determine whether a hydrogen bomb should be constructed, whether it should be used or how it should be used. The responsibility rests with the American people and with their chosen representatives."

Soviet Union Scientists Against Nuclear Power: the father of the Soviet Hydrogen Bomb, A. D. Sakharov andI. Kurchatov. A. Sakharov (Nobel peace laureate 1975) never expressed any remorse for his 
involvement in developing the Hydrogen bomb. Russian scientists: M. D. Milyonşikov, L. A. Artsimoviç, A. D. Sakharov and P. Kapitza who were reluctantly involved in developing the Soviet nuclear program could not voice their concerns and were not allowed to attend to the Pugwash meetings until Gorbachev's Perestroika Movement in 1985.

In response to President Reagan's initiation of a further revitalization of the nuclear arms race by proposing the 'Strategic Defense Initiative', or 'Star Wars' program. Key Soviet scientists Y. Velikov and R. Sagdeev (who took over Artsimovich and Millionshchikov's positions in the Soviet as well as Pugwash meetings) were dismayed with Reagan's decision. In response to the Star Wars program, they organized a committee called, 'Soviet Scientists for Peace and against the Nuclear Threat' known as the CSS.

\section{Weapons of Mass Destruction: Biological Weapons, Chemical Weapons and Nuclear Weapons}

1925 Geneva Protocol prohibits the use but not the possession or development of Biological weapons (BWC). But, when it became available as a poor man's weapon, in 1975, a revised BWC was established which prohibits development, production and stockpiling of biological and toxin weapons. As of 2014, 175 States become party to BWC.

The CWC (Chemical Weapons Convention) prohibited the use of $\mathrm{CW}$, which entered into force in April 1997.

Nuclear Weapons: In 1968 the U.S., and the Soviet Union, England, France and China defiantly reached adequate number of nuclear weapons and declared themselves as default nuclear power status, making themselves an indispensable 'nuclear club' and excluding themselves from the NPT.

\subsection{Ethicality of Dual Use of Nuclear Power}

In fact, US legislation about atomic energy in the fifties, made government loans available to utilities, provided nuclear fuel almost at no cost and made it possible for the US Atomic Energy Commission to leave it largely to the nuclear industry to regulate itself, the condition that burnt fuel consisting Pulutonium-239 was a federal property. During the Cold War, an accelerating nuclear arms race started between the East and the West. The development of nuclear technology was considered as national security and covered by a blanket of official secrecy.

The politicians during the Cold War have been complicit in distorting facts about ionizing radiation and misleading the public by asserting that a low level of radiation may be 'good for health'. In 1954, the U. S. Atomic Energy Act was also amended to implement some of Eisenhower's proposals about international cooperation, and the transfer of the nuclear energy technology to friendly countries. Between 1955 and 1958 the U. S. government signed more than 40 nuclear cooperation agreements marking the beginning of a dual use of nuclear technology, Turkey and Israel had first privilege to sign the agreement and to be part of this act.

In the following years, dual use nuclear reactors began to flourish in the U. S., Europe, the Soviet Union, China and Japan and countries like India and Pakistan, officially promoting large scale dual-use reactors designed to generate electrical energy, so cheap to meter and to maximize the harvesting of plutonium-239 for a weapons program. As a result, estimated quantities of civilian separated plutonium stock at the end of 2005 were: Belgium: 3.3 tons (plus 0.4 in France) France: 81.0 tons (30 foreign-owned) Germany: 12.5 tons (plus 15 in France and UK) India: 5.4 tons, Japan: 5.9 tons (plus 38 in France and UK) Russia: 41.0 tons, Switzerland: $<2.0$ tons (in France and UK) United Kingdom: 105.0 tons (27 foreign owned plus 0.9 abroad) the United States: 20 tons. Global Total 270.0 tons [16].

Unethical Ionizing Radiation Experiments on Humans: since the beginning of the nuclear age, in 
order to justify chronic releases of radiation from nuclear facilities, irresponsible scientists and politicians promote the idea that 'low dose radiation' is good for the health, known as Hormesis. In 1994, by President Clinton's 'new openness' initiation released over 1.6 million pages of classified documents showing that since 1940 the US Atomic Energy Commission has conducted radiological testing on human beings without their consent. Children, pregnant women and male prisoners were injected with orally consumed radioactive materials. This secrecy also applied to commercial nuclear facilities, which made it very difficult for the public to gain access to data about potential safety problems of nuclear power plants. This, in turn, made it virtually impossible for the public to influence either the development of the nuclear industry in the USA, the Soviet Union or in Europe. Most of the nuclear power plants operated virtually without a comprehensive insurance policy, while the right of the public to hold the industry liable for unethical acts and damages in case of a major nuclear accident for all purposes was suspended.

\section{The International Court of Justice, the Highest Court with Undisputed Ethical Responsibility}

The Ethicality of the Threat or Use of Nuclear Weapons: On September 3rd, 1993 the WHO (World Health Organization) has requested an advisory opinion from the ICJ on the following question: "In view of the health and environmental effects, would the use of nuclear weapons by a state in war or other armed conflicts, be a breach of its obligations under international law including the WHO Constitution?" Ironically, after considering the case and receiving oral and written submissions relating to the Legality of the Use by a State of Nuclear Weapons in Armed Conflict, the court did not produce an advisory opinion for the WHO's request. By 11 votes to 3, the court found that the WHO was an incompetent organization on the matter of legality of nuclear weapons, and further, its question does not fit the WHO's activities under the ICJ charters, article 96 (2). As a result of strong judicial and political pressure of nuclear weapon states, the court claimed that WHO, established under the UN charters with the aim of concerning the health and welfare of the world's population, is breaching its constitutions by requesting such a question.

One year later, on December 15th, 1994, before the land mark 1995 NPT review, The General Assembly of the United Nations submitted a new question to the court for an advisory opinion. The UN's resolution of $49 / 75 \mathrm{~K}$, submitted to the court, was adopted by 78 states voting in favor, 43 against, 38 abstaining and 26 not voting. According to this resolution 49/75 K, the following question was created:

On December 15th, 1994, the General Assembly of the United Nations: "Decide, pursuant to Article 96, paragraph 1, of the charter of the United Nation to request the International Court of Justice urgently to render its advisory opinion on the following question: "Is the threat or use of nuclear weapons in any circumstances permitted under international humanitarian law?" Firstly, the court composed of 15 judges elected by the UN General Assembly and UN Security Council, had to make a decision about whether it has a jurisdiction to reply and produce an affirmative opinion on this matter. According to Articles 10, 11 and 13 of the UN Charter, the court decided that the question put to the court in fact had relevance to its activities, including the threat or use of nuclear weapons in international relations.

Despite the opposition of some nuclear and some western states, the court observed that it has competence in respect to advisory opinion based on Article 65, paragraph 1 of the UN Charter. Furthermore, the court also finds that the request of the General Assembly is indeed a legal question, since the court asked to rule on the compatibility of the threat or use of nuclear weapons within the rules of 
International Law. After 18 months of hearings, including intensive political and legal debate-liberation, on July 8th, 1996, the court punted a whale advisory opinion back to the UN. The final paragraph of the court advisory opinion reads [17]:

"The court decides, by thirteen votes to one, to comply with the request for an advisory opinion. The court replies on the following manner to the question put by the General Assembly:

A. unanimously: there is neither customary nor conventional international law any specific authorization of the threat or use of nuclear weapons.

B. By eleven votes to three: there is neither customary nor conventional international law any comprehensive prohibition of the threat or use of nuclear weapon as such.

C. Unanimously: A threat or use of force by means of nuclear weapons that is contrary to Article 2, paragraph 4 , of the Charter of the United nations and that fails to meet all the requirements of Article 51 is unlawful.

D. Unanimously: A threat or use of nuclear weapons should also be compatible with the requirements of the international law applicable in armed conflict, particularly those of permissible and rules of international humanitarian law, as well as with specific obligations under treaties and other understanding which expressly deal with nuclear weapons.

E. By seven votes to seven, by the president of the court casting vote: "It follows from the abovementioned requirements that the threat or use of nuclear weapons would generally be contrary to the rules of international law applicable in armed conflict, and particularly the principles and rules of humanitarian law; However, in view of the current state of international law, and of the elements of fact of its disposal, the Court cannot conclude definitively whether the threat or use of nuclear weapons would be lawful or unlawful in an extreme circumstances of self-defense, in which the very survival of a State would be at stake;"

F. Unanimously: There exists an obligation to pursue in good faith and bring to a conclusion negotiations leading to nuclear disarmament in all its aspects under strict and effective international control."

Is it an ethical or judicial delusion? A closer look at dubious assumptions behind the court's opinion shows it to be perverse and contradictory to all known international ethics/norms and lawful analysis. In fact, it is an endorsed permission, issued by the highest court of the world, to the nuclear states to be able to use nuclear weapons when they deem to be in the 'state of survival'. The court simply considered the very survival of a nuclear state more important than the rest of the beings on our planet and, one wonders if the same question was put before the ICJ in 2017 and what would be outcome. The court opinion highlighted an important fact that universal declaration of human rights had been ignored throughout the deliberation of the court proceedings. The court decision could have had two profound consequences: firstly, it would constrain both the pace of vertical and horizontal proliferation and speed up the disarmaments and abolish all nuclear weapons.

Ethical Confession of the President of the Court-Judge Bedjaui quoted: "The very nature of this blind weapon therefore has a destabilizing effect on humanitarian law which regulates discernment in the type of weapon used. Nuclear weapons, the ultimate evil, destabilize humanitarian law which is the law of the lesser evil. The existence of nuclear weapons is therefore a challenge to the very existence of humanitarian law, not to mention their long-term effects of damage to the human environment, in respect to which the right to life can be exercised."

In 1996 international court opinion unfortunately, and carelessly, conceived preconditions for the survival of the states, thus remaining the greatest barrier to achieve a 'zero nuke-free' world. An adequate, achievable and equitable solution to 'zero 
nuke' on our planet requires a new NPT framework that meets the needs and concerns of developing countries. The court admits that, in the view of 1996's state of international law, the complexity of the original UN question, and of the existing facts at its disposal, it does not have sufficient elements, to enable to conclude with certainty, that the use of nuclear weapons are at variance with the principles and rules of the law applicable in armed conflict in any circumstance. Ironically, the court also observe that, because of 7 to 7 votes for item E, it could not reach a definite conclusion on their creative version of the UN question that, as to the legality of the use of nuclear weapons by a state in a unique circumstance of 'self-defense', in which its very survival would be at stake.

\subsection{Nuclear Deterrence versus a World Free of} Nuclear Weapons

In the early stage of the Cold War, A. Teller, known as the father of the hydrogen bomb said that: 'deterrence required more weapons, and in order for new weapons to be developed nuclear tests needed to continue.' However, at the end of the Cold War, H. Kissinger, referring to the nuclear deterrence, quoted: "One steady and unchangeable is now doubtful and vague". As a matter of fact, that the ICJ 1996 opinion connecting the survival of the state to nuclear weapons and to extend nuclear deterrence, was dismissed by a hysterical manifesto, signed by G. P. Shults, W. J. Perry, H. Kissinger, and S. Nunn, and published on January 4th, 2007 on the Wall Street Journal.

"Nuclear weapons today present tremendous dangers, but also an historic opportunity. U.S. leadership will be required to take the world to the next stage--to a solid consensus for reversing reliance on nuclear weapons globally as a vital contribution to preventing their proliferation into potentially dangerous hands, and ultimately ending them as a threat to the world. Deterrence continues to be a relevant consideration for many states with regard to threats from other states. But reliance on nuclear weapons for this purpose is becoming increasingly hazardous and decreasingly effective" [18].

As of 2014, there are approximately 23,400 nuclear weapons located at 111 different sites in 14 countries. Half of which are trigger ready or deployable in a short time. Russia $(13,000)$ and the United States $(9,400)$ possess $96 \%$ of such weapons. The other nuclear club members: Britain (180), China (240), France (300) along with de Facto countries such as India (80), Israel (100), Pakistan (90) are also added to this monumental list. In addition, non-nuclear NATO allies such as Belgium, Turkey, Germany, Italy and Holland, house about 200 the U.S. nuclear bombs [19].

\section{The NPT (Nuclear Non-proliferation Treaty)}

The main objectives of the NPT were to stop the nuclear arms race's 'vertical proliferation' to achieve elimination of existing nuclear weapons, and further, halt more countries from joining the five declared nuclear states 'horizontal proliferation' and offer developing countries access to use nuclear power for peaceful purposes. However, these peaceful uses of nuclear power projects are happened to be geopolitically motivated and did provide new breeding grounds for nuclear weapon programs that were disguised under the guise of a nuclear technology transfer agreements. Ironically, the NPT, still being portrayed as the only universal international treaty that exists since the Second World War, had failed to neither slow nor stop the nuclear arms race. On the contrary it opened a legal platform for clandestine nuclear weapons development in member countries Such as Iran, North Korea.

Ethical Evolution or Zero Nukes Revolution: The NPT concept was initiated by Irish Minister of External Affairs, Frank Aiken in 1958, and the Ten Commandments/Articles of NPT or 'holy laws of the 
nuclear weapon states' were inscribed 55 years ago during the 1962's, 18 Nation Disarmament Conference in Geneva, where the US submitted a first draft of the NPT treaty to the General Assembly of the United Nations. The NPT was approved by a vote of 95 to 4 with 21 abstentions. A strategic nuclear alliance was created including the US, the Soviet Union, England, China and France. In the following years, the USA and the USSR played a leadership role in negotiation and in finalizing the NPT which went into force in 1970. In early the 1980's, when the number of nuclear warheads reached a peak of 70,000 around the world, further negotiations continued every five years, and in the 1995 review conference the treaty was extended indefinitely.

Past, Present and Future of the NPT: Bad, worst and unpredictable. During May of 2015 at the NPT meeting, the NPT member's states gathered at the United Nations Headquarters in New York, for the treaty's traditional five year review and further reaffirmed the preservation and integrity of the NPT. As usual, the conference was opened with principle objectives of seeking a safer and risk-free world for all and to achieve the peace, security and survival of a world without nuclear weapons. However, the conference also reaffirmed that the NPT still fosters the development of the 'peaceful' use of nuclear energy and its fuel cycles by which the nuclear weapons industry has been maintaining a parallel progress during the last 67 years.

Ethical Dilemma of NPT: the outcome of the 2015 NPT Conference proved once more, that it is inherently fragile and its effectiveness depends on: firstly the cooperation of nuclear states, and secondly complete global ratification of zero nukes. However, given the fact that, the International Court of Justice's opinion, the WHO, and the IAEA (which collectively operate in a complicated complex of the United Nations political environment), general public have been bound to face and deal with serious problems concerning tenprincipals of the NPT, which created more mismatches between 'haves' and 'have-nots' and especially establishing a nuclear free zone in the Middle East. As a result, a low morale which continues to plaque the NPT's effectiveness, and still recognizes the IAEA as the only authority as a global watch dog, has been harshly criticized.

\section{IAEA (International Atomic Energy Agency)}

An Ethical Invention of the Nuclear Industry: In 1957, the IAEA was born under the umbrella of the United Nations as only authority to safeguard, promote and regulate civilian nuclear insulations around the world, with exception of national research labs and reprocessing military reactors throughout the world. The IAEA, as organizer and promoter of a global alliance on nuclear technology was charged with the dual responsibility of promoting the useful use of nuclear energy worldwide and also to conduct the official inspections in civilian nuclear facilities in the member countries so that they do not engage in any nuclear weapons programs. However, during the last 60 years, any attempts by the IAEA to impose ethical conduct of business or enforcing effective safety measures have been silenced by the nuclear industry.

Global nuclear watchdog with no teeth; During the fastest expansion of nuclear technology, financially cemented military and civilian nuclear establishments opened avenues to unparalleled opportunities for the university research centers and defense related contractors. Governments and major corporations provided massive financing for new equipment and 'state of the art' computers. Ironically, this revolving door that existed between the military and civilian nuclear industry is still functioning under the watchful eyes and ears of the IAEA. After 60 years of being an ineffective organization, in 2007, the IAEA published an official report concerning with code of ethics for nuclear industry operating organizations titled. "Establishing a Code of Ethics for Nuclear Operating Organizations" [20], in which they admitted that 
ethical dilemmas in the nuclear industry are still lingering.

\subsection{The IAEA's Definition of Business Ethics}

"Is the branch of ethics that examines ethical rules and principles within a commercial context; the various moral or ethical problems that can arise in a business setting; and any special duties or obligations that apply to persons who are engaged in commerce", "Formal business ethics programmers are relatively new. Although a handful of companies have had them for twenty to thirty years, the majority of business ethics programs are no more than a few years old. In the past 10 years there has been a significant increase in large and multinational organizations that have codes of ethics and business conduct. In many Member States and particularly for multi-national organizations, having a code/policy on ethics is now considered one of the hallmarks of a well-managed organization". Thus, the only one way to do business as a nuclear industry operating organization is with high ethical standards in all respects. The lifetime of nuclear facilities can be 60 years or more. Taking into account the management of spent fuel and radioactive waste, the period to consider is even longer.

"Experience has shown that, even in organizations that have clear codes of ethics, there are situations for which application of this code is a challenge. Appendix E provides examples of ethical dilemmas that individuals in a nuclear industry organization might face. As these examples illustrate, ethical dilemmas for individuals in nuclear industry organizations are often the result of fear, greed, peer or political pressure, and/or financial pressures. They may also be the result of poorly thought out decisions or those made for the sake of expediency" [20].

\subsection{WEF (The World Economic Forum)}

WEF's definition of Global Risks and Trends: A global risk is an uncertain event or condition that, if it occurs, it can cause significant negative impact on several countries or industries within the next 10 years. A global trend is a long-term pattern that is currently taking place and that could contribute to amplifying global risks and/or altering the relationship between.

It was established in 1971 as a not-for-profit foundation and is headquartered in Geneva, Switzerland. It is independent, impartial and not tied to any special interests. The Forum strives in all its efforts to demonstrate entrepreneurship in the global public interest while upholding the highest standards of governance. Moral and intellectual integrity is at the heart of everything it does.

WEF's Global Risk Perception: Global Risk Landscape: 2016 WEF report stated that "Almost 750 experts and decision makers in the World Economic Forum's Multi stake holder communities responded to its 2016's Global Risks Perception Survey. The survey asked respondents to consider 29 global risks - categorized as societal, technological, economic, environmental or geopolitical-over a 10-year time horizon, and rate each according to their perceived likelihood of it occurring and impact if it does.

After its presence in the top five most impactful risks for the past three years, the failure of climate change mitigation and adaptation has risen to the top and is perceived in 2016 as the most impactful risk for the years to come, ahead of weapons of mass destruction, ranking $2 \mathrm{nd}$, and water crises, ranking $3 \mathrm{rd}$. Large-scale involuntary migration was also rated among the top five for impact, as was severe energy price shock (increase or decrease)" [21].

The World Economic Forum's 2016 Global Risk Landscape report included categories and their description of low-probable, high-impact risks resulting from human activities. The goal of these reports, published every year, is to build resilience to global risks. For 60 years, the economists, scientist and environmentalists around the world have constantly proved that the cost of nuclear power, from financial investment to the risk of proliferation of 
nuclear weapons, catastrophic accidents, is simply too unpredictable and a high risk energy source. The WEF knows that radioactive emissions from Fukushima plant are still lingering and have exceeded by (several hundred folds) the radioactive contamination of the bombs dropped in Hiroshima and Nagasaki combined. Unfortunately, the WEF has failed again to include the global ionizing radiation risks in 2016 Forum's report.

\section{Ethical Confessions}

J. P. Oppenheimer: quoted "Now I am become a death, the destroyer of worlds". In 196, Prof. 1 Pauling Lindus said that, "The Dead will inherit the earth", Prof. Enrico Fermi one of the founders of modern nuclear physics once called nuclear weapons scientists, "a Monomaniac with much mania", Nikita Khrushcev also said that "The living would envy the dead", president Ronald Reagan quoted, "a nuclear war cannot be won and must never be fought", Kissinger quoted. "Once steady and unchangeable is now doubtful and vague." In the December 2014 Vienna conference (Austria), 68 states put forward a document, known as the 'Vienna Pledge' that seeks to 'fill the gap for the prohibition and elimination of nuclear weapons.'

J. W. Gofman, professor of emeritus of molecular and cellular biology and nuclear physical chemistry at the University of California, Berkley said: "licensing a nuclear power plant is in my view, licensing random premeditated murder", the Exelon's chairman Mr. John Power's comments about nuclear revival; Exelon, is the largest and most experienced energy corporation in the world, currently operating 17 nuclear reactors in the U.S, “I don't see this technology fulfilling a major role. If you start off with a $\$ 6$ billion project, you can't very well afford to have it turn into $\$ 12$ billion. No utility executive ever was foolish enough to say that nuclear energy would make electricity too cheap to meter. That was Lewis Strauss. J. Power quoted that was a very foolish statement" [22].

\section{Conclusion}

In the twenty first century, national security, climate change, population explosion and energy economics are undisputable rationales that provide a global platform for scientists and politicians alike to mitigate existing environmental problems. However, the ethical question of the health hazards of ionizing radiation, the ethical problem of the disposal of nuclear waste, the ethical problem of the risk of catastrophic nuclear power plant accidents and redemption costs, the ethical problem of nuclear proliferation, are all collectively contributing to a new chapter in human history.

Historical facts and official reports which are briefly outlined above clearly prove that a code of ethics never existed in the nuclear industry; the risks of man-made ionizing radiation are too great and unpredictable. Finally, any superficial attempt by the IAEA or the nuclear industry to eliminate existing ionizing radiation sources in this century is untenable and unsustainable and the latest unethical nuclear industry resurgence, namely, “One's Man's Nuclear Waste is Another Man's Treasure" is nothing but will be man-made ionizing radiation treasure forever.

\section{Acknowledgment}

The author would like to thank to Mrs. Marry Jimenez for her valuable comments. The Green Think Tank of Turunch Foundation is a nonprofit (501) (c) 3 foundation in the United States, and does not accept any donations.

\section{References}

[1] Butler, D. 2011. "Reactors, Residents and Risk." Nature 21st April.

[2] Kristensen, H. M., Norris, R. S., and McKinzie, M. 2006. Chinese Nuclear Forces and US Nuclear War Planning. Washington, D. C.: Federation of American Scientist.

[3] The IAEA. 2008. Estimation of Global Inventories of Radioactive Waste and Other Radioactive Materials. Vienna, IAEA.

[4] The IAEA. 2014. Nuclear Safety Review. Vienna, IAEA.

[5] The IAEA. 2015. "The Purpose and Scope of IAEA TM." Technical Meeting on Fire Protection Approaches and 
Experiences in Nuclear Power Plants, May 27-29, Vienna, Austria.

[6] Busby, C. 2013. "Aspects of DNA Damage from Internal Radionuclides." In New Research Directions in DNA Repair, edited by Chen, C. Bremen. Germany: INTECH.

[7] Schmitz-Feuerhake, I., Busby, C., and Pflugbeil, S. 2016. "Genetic Radiation Risks: a Neglected Topic in the Low Dose Debate." Environ Health Toxicol 31: e2016001.

[8] Falk, J. R. 2008. Nuclear Power's Role in Generating Electricity. Washington, D. C.: Congressional Budget Office.

[9] Koplow, D. N. 2011. Nuclear Power: Still Not Viable without Subsidies. Washington, D.C.: Union of Concerned Scientists.

[10] Gregorio, D., Saiz, S., Gjerde, M., Isorena, P., Laputz, A., and Roddy, F. et al. 2008. Water Quality Control Policy on the Use of Coastal and Estuarine Waters for Power Plant Cooling. State Water Resources Control Board California Environmental Protection Agency.

[11] The IAEA. 1999. Inventory of Radioactive Waste Disposals at Sea. Vienna, Germany.

[12] "Chinese Nuclear Test could have Taken the Lives of 1.48 Million People." Accessed December 10, 2016. http://www.pravdareport.com/science/earth/21-04-2009/1 07435-china_nuclear_tests-0/.
[13] Tsar Bomba. Accessed December 10, 2016. https://en.wikipedia.org/wiki/Tsar_Bomba.

[14] Father of All Bombs. Accessed December 10, 2016. https://en.wikipedia.org/wiki/Father_of_All_Bombs.

[15] Backgrounder on Russian Fuel Air Explosives ("Vacuum Bombs") Human Rights Watch. Hrw. org. 2000-02-01. Retrieved 2013-04-23.

[16] Frank, V. H. 2007. ManagingSpent Fuel in the United States: The Illogic of Reprocessing. International Panel on Fissile Materials.

[17] International Court of Justice. 1996. Legality of the Threat or Use of Nuclear Weapons, Advisory Opinion, Reports of Judgments, Advisory Opinions and Orders.

[18] Shultz, G. P., Perry, W. J., Kissinger, H. A., and Nunn, S. 2007 "A World Free of Nuclear Weapons." The Wall Street Journal 4: A15.

[19] Kristensen, H. M., and Norris, R. Nuclear Notebook. Accessed December $\quad 10, \quad 2016$ http://thebulletin.org/nuclear-notebook-multimedia.

[20] The IEAE. 2007. Establishing a Code of Ethics for Nuclear Operating Organizations. Vienna, Germany.

[21] The World Economic Forum's 2016 Global Risk Landscape Report. Accessed December 10, 2016. /http://reports.weforum.org/global-risks-2016/.

[22] Kristensen, H., and Norris, R, S. "US Nuclear Forces, 2008." Bulletin of Atomic Scientists 64 (4). 